University of Nebraska - Lincoln

DigitalCommons@University of Nebraska - Lincoln

\title{
Groundwater nutrient concentrations during prairie reconstruction on an lowa landscape
}

\author{
M.D. Tomer \\ USDA-Agricultural Research Service, mark.tomer@ars.usda.gov \\ K.E. Schilling \\ lowa Department Natural Resources \\ C.A. Cambardella \\ USDA-Agricultural Research Service \\ P. Jacobson \\ Grinnell College \\ P. Drobney \\ US Fish and Wildlife Service
}

Follow this and additional works at: https://digitalcommons.unl.edu/usdaarsfacpub

Part of the Agricultural Science Commons

Tomer, M.D.; Schilling, K.E.; Cambardella, C.A.; Jacobson, P.; and Drobney, P., "Groundwater nutrient concentrations during prairie reconstruction on an lowa landscape" (2010). Publications from USDA-ARS / UNL Faculty. 880.

https://digitalcommons.unl.edu/usdaarsfacpub/880

This Article is brought to you for free and open access by the U.S. Department of Agriculture: Agricultural Research Service, Lincoln, Nebraska at DigitalCommons@University of Nebraska - Lincoln. It has been accepted for inclusion in Publications from USDA-ARS / UNL Faculty by an authorized administrator of DigitalCommons@University of Nebraska - Lincoln. 


\title{
Groundwater nutrient concentrations during prairie reconstruction on an Iowa landscape
}

\author{
M.D. Tomer ${ }^{\mathrm{a}, *}$, K.E. Schilling ${ }^{\mathrm{b}}$, C.A. Cambardella ${ }^{\mathrm{a}}$, P. Jacobson ${ }^{\mathrm{c}}$, P. Drobney ${ }^{\mathrm{d}}$ \\ a National Laboratory for Agriculture and the Environment, USDA-Agricultural Research Service, 2110 University Blvd, Ames, IA 50011-3120, USA \\ b Iowa Geological Survey Bureau, Iowa Dept Natural Resources, Iowa City, IA, USA \\ ' Department of Biology, Grinnell College, Grinnell, IA, USA \\ d Neal Smith National Wildlife Refuge, US Fish and Wildlife Service, Prairie City, IA, USA
}

\section{A R T I C L E I N F O}

\section{Article history:}

Received 3 June 2010

Received in revised form 29 July 2010

Accepted 3 August 2010

Available online 1 September 2010

\section{Keywords:}

Ecosystem restoration

Groundwater quality

Nitrate-N

Phosphorus

Land use change

Environmental legacy

\begin{abstract}
A B S T R A C T
One anticipated benefit of ecosystem restoration is water quality improvement. This study evaluated $\mathrm{NO}_{3}-\mathrm{N}$ and phosphorus in subsurface waters during prairie establishment following decades of row-crop agriculture. A prairie seeding in late 2003 became established in 2006. Wells and suction cup samplers were monitored for $\mathrm{NO}_{3}-\mathrm{N}$ and phosphorus. Nitrate- $\mathrm{N}$ varied with time and landscape position. Nondetectable $\mathrm{NO}_{3}-\mathrm{N}$ concentrations became modal along ephemeral drainageways in 2006, when average concentrations in uplands first became $<10 \mathrm{mg} \mathrm{NO}{ }_{3}-\mathrm{NL}^{-1}$. This decline continued and upland groundwater averaged near $2 \mathrm{mg} \mathrm{NO} \mathrm{N}_{3}-\mathrm{N} \mathrm{L}^{-1}$ after 2007. The longer time lag in $\mathrm{NO}_{3}-\mathrm{N}$ response in uplands was attributed to greater quantities of leachable $\mathrm{N}$ in upland subsoils. Spatial differences in vadose-zone travel times were less important, considering water table dynamics. Phosphorus showed a contrasting landscape pattern, without any obvious temporal trend. Phosphorus was greatest along and near ephemeral drainageways. Sediment accumulation from upland agricultural erosion provided a source of $P$ along drainageways, where shallow, reductive groundwater increased P solubility. Phosphorus exceeded eutrophication risk thresholds in these lower areas, where saturation-excess runoff could readily transport P to surface waters. Legacy impacts of past agricultural erosion and sedimentation may include soluble phosphorus in shallow groundwater, at sites prone to saturation-excess runoff.
\end{abstract}

Published by Elsevier B.V.

\section{Introduction}

Changes in land use are known to affect changes in water quality, given sufficient lag time to observe the change (Meals et al., 2010). In small watersheds (i.e., $<250$ ha), $\mathrm{NO}_{3}-\mathrm{N}$ concentrations in tile drainage and seepage water have responded to land use change within 3-6 years (Jaynes et al., 2004; Owens et al., 2008), but ground water travel times may lengthen the time needed to observe a full response in groundwater flow systems to decades (Schilling et al., 2007; Tomer and Burkart, 2003). Ecosystem restoration is one land use change that is expected to result in improved water quality. However few large-scale restoration efforts have been implemented to help understand landscape scale water quality responses to restoration efforts.

One such effort is large-scale prairie reconstruction occurring on former row-crop fields at the Neal Smith National Wildlife Refuge (NSNWR) near Prairie City, IA (Fig. 1). The NSNWR represents one of the first attempts at agricultural land use reversion

\footnotetext{
* Corresponding author. Tel.: +1 5152940213.

E-mail address: mark.tomer@ars.usda.gov (M.D. Tomer).
}

towards ecosystem restoration at a watershed scale, and thus provides a natural laboratory for assessing the groundwater quality response resulting from reconstruction of a perennial grassland ecosystem within an agricultural landscape. Between 1991 and 2005,1224 ha of prairie plantings were undertaken in the 5218 ha Walnut Creek watershed (Schilling and Spooner, 2006). Results from a 10 year paired watershed study indicated that placement of reconstructed prairie at the NSNWR reduced watershed scale stream concentrations by $1.2 \mathrm{mg} \mathrm{NO}_{3}-\mathrm{N} \mathrm{L}^{-1}$ over 10 years (Schilling and Spooner, 2006). The reduction was significant, but was less than expected. However, the decrease in $\mathrm{NO}_{3}-\mathrm{N}$ was measured at the watershed outlet, and represented integrated contributions from the entire basin, including both areas in reconstructed prairie and crops. Therefore, questions remain regarding actual rates of $\mathrm{NO}_{3}-\mathrm{N}$ concentration decrease associated with reconstruction of tallgrass prairies. This issue is important because it influences setting of water quality targets in watersheds and judgments about rates of progress towards achieving those targets.

Recently, groundwater level and quality comparisons were made across a chronosequence of prairie plantings at the NSNWR (Schilling and Jacobson, 2010). Nitrate concentrations in groundwater beneath a 13 year chronosequence were found to have 


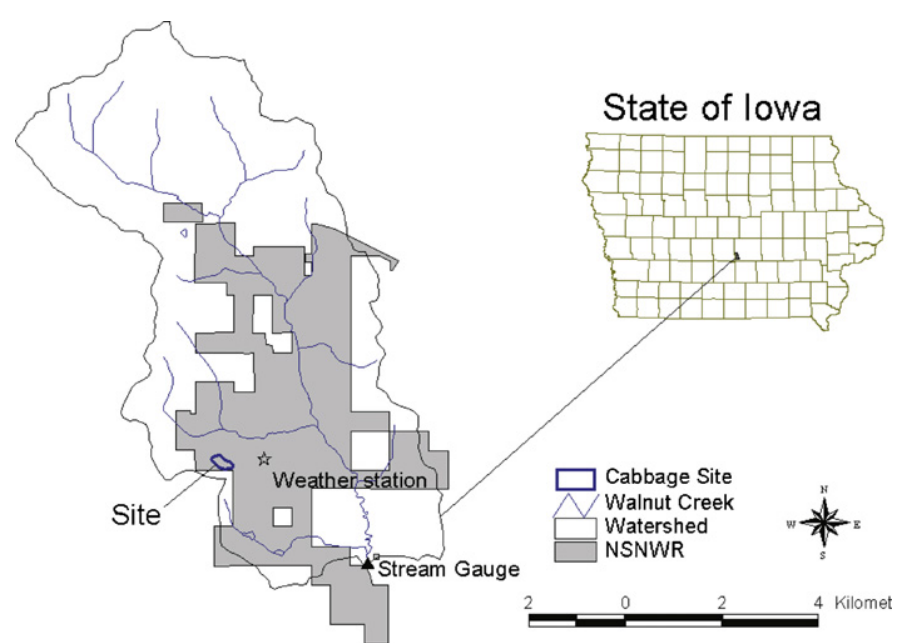

Fig. 1. Location of research site in the state of Iowa and within the Neal Smith National Wildlife Refuge (NSNWR), found in Jasper county.

decreased, on average, $0.58 \mathrm{mg} / \mathrm{l}$ per year, but no trends in phosphorus concentrations were detected. Despite controlling for landscape position and soil type, the rate of $\mathrm{NO}_{3}-\mathrm{N}$ decrease varied by season and year, ranging from 0.3 to nearly $1 \mathrm{mg} / \mathrm{l}$ per year. In a chronosequence involving former agricultural systems, it is difficult to control for historical land management among many different locations and former operators.

The objective of this study was to characterize changes in nutrient concentrations in subsurface waters during conversion of an agricultural, row-cropped field to a reconstructed prairie within a single field. Focusing on water quality changes at a single site allows for improved understanding of initial conditions and quantification of the time needed to observe water quality effects. Concentrations of $\mathrm{NO}_{3}-\mathrm{N}$ and phosphorus were monitored in groundwater collected from wells and soil leachate collected from suction cup samplers. The study further evaluated how landscape position influenced nutrient concentrations and trends.

\section{Materials and methods}

\subsection{Site description and prairie reconstruction}

The study site is located near the western edge of the NSNWR (Fig. 1). The NSNWR is located in the Walnut Creek watershed (5218 ha) and is within the Southern Drift Plain region of Iowa, an area with steeply rolling hills and well-developed stream drainage networks (Prior, 1991). In this region, sedimentary bedrock is overlain by a sequence of fine-grained deposits of glacial till, loess and alluvium. Upland soils formed in loess or till are mainly siltyclay or clay loams, and at the research site are classified under the tama (typic argiudolls), mahaska (aquertic argiudolls), downs (mollic hapludalfs), and killduff (dystric eutrochrepts) soil series (Nestrud and Worster, 1979; Soil Survey Staff, 2003). Details on the stratigraphy and surficial geology of the site were given by Schilling et al. (2007). The climate is humid and continental with average annual precipitation of about $850 \mathrm{~mm}$. The greatest monthly rainfall totals typically occur in May and June but convective storms during summer and snowfall during winter also contribute significant precipitation.

The research site encompassed 7 ha, including two ephemeral drainageways and their contributing catchments (Fig. 2). The site was in long-term agricultural production under a corn (Zea mays L.) and soybean (Glycine $\max$ L. Merr.) rotation through 2003. In December 2003, following soybean harvest, the site was broad-

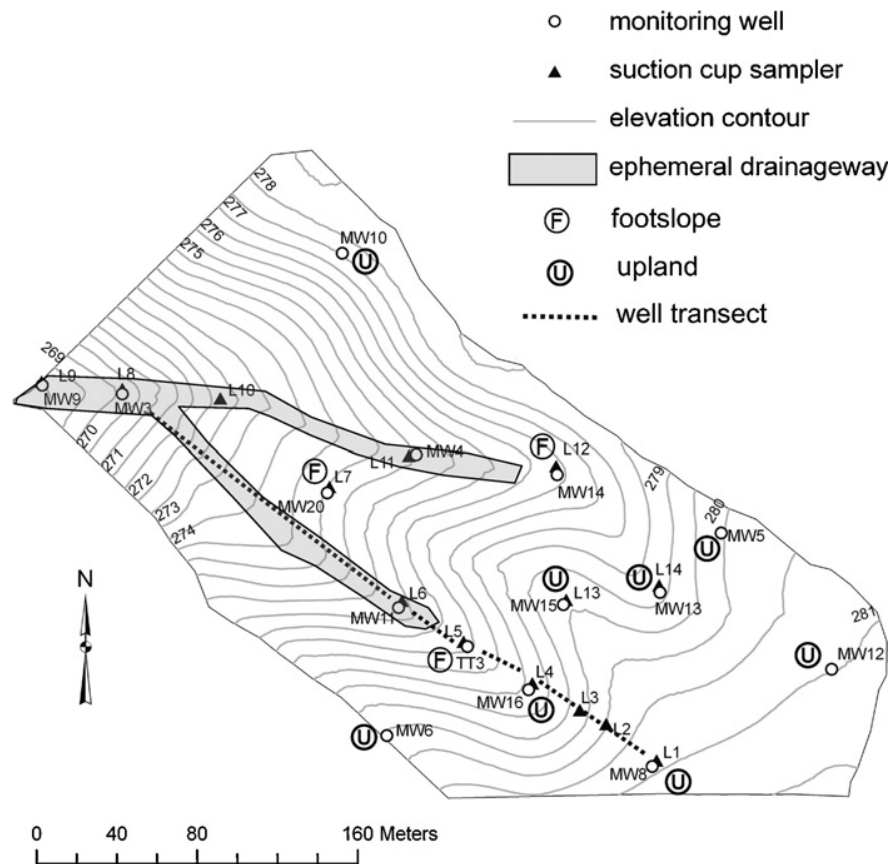

Fig. 2. Detailed map of the research site, showing topography, drainageways, monitoring installations with landscape positions identified outside the drainageways, and placement of a well transect plotted in Fig. 4.

cast seeded with a mix of native grasses and forbs. The seed mix was obtained through machine harvesting of grass seeds from local remnant prairies, which was diversified with seeds of rarer species (mostly forbs) that were harvested by hand. Canada wildrye (Elymus canadensis) was also added to provide as a cool-season nurse crop that establishes quickly but diminishes in a few years, especially if prescribed fire is used during spring. During 2004, the site was mowed twice to reduce weeds and favor the developing native plants. A diversity of species emerged and developed during 2004, including a few notable blooming specimens of pale purple coneflower (Echinacea pallida), thimble weed (Anemone cylindrica), and rough blazingstar (Liatris aspera). By the end of the 2005 growing season, a canopy of Canada wildrye was established, providing cover for a variety of slower-establishing species to increase in subsequent years. Controlled burns were conducted in January 2006 and April 2007-2009 to help manage prairie establishment and control weeds. This helped to reduce the canopy of Canada wild rye to a more occasional distribution, and to diversify the prairie plant community. In parallel research, the developing prairie plant community and soil transects are being monitored along topographic gradients to provide information about plant-soil-water interactions and their changes through time in a developing prairie.

\subsection{Monitoring installations}

Groundwater monitoring wells were installed at fifteen locations in 2001 and 2003 to represent a range of groundwater conditions across the site (Fig. 2). Installation was described by Schilling et al. (2007). Briefly, boreholes were drilled with a truck-mounted hydraulic probe, and wells with screens lengths of 3.0-4.5 m were installed to allow sampling of groundwater at the water table under a range of seasonal/climatic conditions. The screen lengths were sand packed and capped with a bentonite seal. In April 2004, suction cup samplers (Grossman and Udluft, 2006) were installed at fourteen locations, at depths of 1.2 and $2.4 \mathrm{~m}$ (Fig. 2). Boreholes were again cored with a hydraulic probe to provide access for these installations. Hydraulic contact between the 
ceramic cup and surrounding soil was ensured by pouring about $250 \mathrm{ml}$ of a silica flour and distilled water slurry into the borehole prior to inserting the samplers. The top of each sampler was sealed with bentonite. Samplers were not installed at $2.4 \mathrm{~m}$ where saturated conditions prevented core extraction to that depth. To complete these installations, plastic well caps and sampling tubes from the suction cup samplers were set just below ground surface and covered with metal utility boxes to protect from fire damage. Ground surface and top-of-casing elevations were surveyed with a differential GPS survey unit. Near the time of the prairie seeding, a topographic survey of the site was conducted with a real-time kinematic GPS system with local base control. The GPS data were processed to produce a $2 \mathrm{~m}$ grid elevation model of the site.

\subsection{Sampling and analyses}

Water sampling was initiated in 2002 and conducted on a nearmonthly basis through 2003 , followed by quarterly to semi-annual sampling from 2004 through 2007, and then monthly sampling again during the 2008 and 2009 field seasons (April through November). Water table depths were measured in wells prior to sampling, except during 2005 and 2006. Dry conditions sometimes prevented sample recovery from suction cup samplers, particularly from mid-summer through early autumn. All samples were analyzed for $\mathrm{NO}_{3}-\mathrm{N}$ using $\mathrm{Cd}$ reduction and flow injection analysis (Wood et al., 1967), with a detection limit of $0.5 \mathrm{mg} \mathrm{NO} \mathrm{NL}_{3}-\mathrm{N} \mathrm{L}^{-1}$ for samples collected prior to 2004 and $0.3 \mathrm{mg} \mathrm{NO}_{3}-\mathrm{N} \mathrm{L}^{-1}$ thereafter. Groundwater samples were also analyzed for ammonium using flow injection (APHA, 1998) with the same detection limits. Beginning in 2006, samples were also analyzed for phosphorus concentrations using EPA method 365.1 (O’Dell, 1993). Groundwater (well) samples were passed through a $0.45 \mu \mathrm{m}$ filter in the field at the time of sample collection. However, samples from suction cup samplers were not filtered as these samplers had a nominal pore size estimated to be $1.45 \mu \mathrm{m}$. The detection limit for phosphorus was $0.01 \mathrm{mg} / \mathrm{l}$ for filtered groundwater samples, but samples collected from suction cup samplers were digested with acid-persulfate, and resulting in sample dilution that increased the detection limit to $0.02 \mathrm{mg} / \mathrm{l}$. Herein both are referred to as simply phosphorus concentration but the $\mathrm{P}$ data from the two types of sampling installations are not directly comparable, given P associated with extremely fine particulate matter ( 0.45 to about $1.45 \mu \mathrm{m}$ in size) could be included in the suction cup data.

To evaluate the impact of landscape position on nutrient concentrations, sampling locations were classified as drainageway, footslope, or upland as follows (refer to Fig. 2). Upland well IDs were 'MW' $5,6,8,10,12,13,15$, and 16 , and upland suction cup sampler IDs were 'L' 1 through 4, 13 and 14. Footslope well IDs were 'MW' 14 and 20 and TT3, and footslope suction cup sampler IDs were 'L' 5, 7, and 12. The footslope wells were the three wells that were vertically and horizontally nearest the drainageways, and were just above the top of each drainageway and at the base of the ridge separating the drainageways. The footslope locations were chosen to represent a transition between upland and drainageway groundwater conditions. Drainageway well IDs were 'MW' 3, 4, 9 and 11 , and drainageway suction cup sampler IDs were 'L' 6, 8, 9, 10, and 11 (see Fig. 2). Among the suction cup samplers installed at $2.4 \mathrm{~m}$ depth, only one was located in a drainageway position (saturated conditions usually prevented coring to that depth). Therefore, lacking replication, no results are reported for deep suction cup samplers in the drainageways. The nutrient concentration data were averaged by sampling method and depth, date, and landscape position for plotting. Statistical analyses were conducted to evaluate trends in time and differences among landscape positions. The strength of temporal trends for each landscape position were tested by calculating non-parametric(Spearman rank and Kendall's

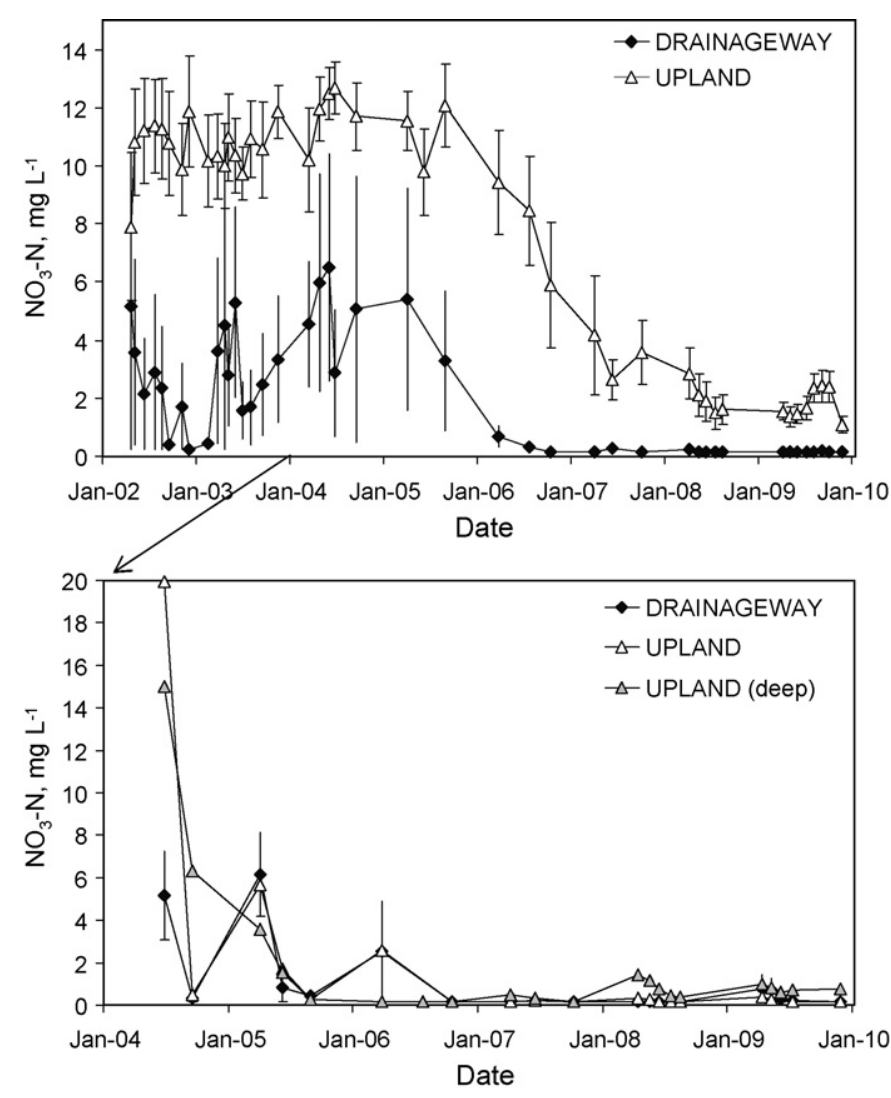

Fig. 3. Upper plot: average $\mathrm{NO}_{3}-\mathrm{N}$ concentrations in groundwater sampled from wells in upland positions and along ephemeral drainageways. Lower plot: average $\mathrm{NO}_{3}-\mathrm{N}$ concentrations in water collected from suction cup samplers in uplands (1.2 and $2.4 \mathrm{~m}$ depth), and along drainageways ( $1.2 \mathrm{~m}$ depth). Error bars indicate standard deviation.

tau-b) correlation coefficients. Differences among landscape positions were tested using the non-parametric Kruskal-Wallis test. For upland groundwater, a site-average rate of decrease in $\mathrm{NO}_{3}-\mathrm{N}$ concentrations was estimated by a linear regression with time, to compare this single site's results to those of a multi-site chronosequence of groundwater nitrate among prairie reconstructions at NSNWR (Schilling and Jacobson, 2010). All statistical tests were run using SAS Analyst, under SAS Ver. 9.2 (SAS Institute, 2010).

Soil coring was conducted in autumn 2004, and a subset of five cores taken along the drainageways and five from upland positions were used to estimate the range in soil carbon and nitrogen across the landscape. Soil samples were taken from five depths at each core location (0-0.15, 0.15-0.30, 0.30-0.60, 0.60-0.90, and 0.90-1.20 m and analyzed for total carbon and total nitrogen using a dry combustion method (Nelson and Sommers, 1986). Inorganic carbon was determined by a modified pressure calcimeter method (Scherrod et al., 2002) and results subtracted from total carbon to obtain organic carbon. Carbon to nitrogen ratios were calculated based on mass concentration, averaged and plotted by depth.

\section{Results and discussion}

\subsection{Nitrate-nitrogen}

When still under agricultural production (prior to December 2003), groundwater $\mathrm{NO}_{3}-\mathrm{N}$ concentrations were significantly greater in uplands compared to the ephemeral drainageways $(p<0.05)$, averaging $10.6 \mathrm{mg} / \mathrm{l}$ in upland wells and $2.5 \mathrm{mg} / \mathrm{l}$ in drainageway wells (Table 1, Fig. 3). The difference in concentrations resulted from greater denitrification occurring in the saturated, 
Table 1

Summary of $\mathrm{NO}_{3}-\mathrm{N}$ concentrations found in groundwater and soil water during three periods of prairie reconstruction, and at three landscape positions.

\begin{tabular}{|c|c|c|c|c|}
\hline Sampling method/depth and time interval & Landscape position & Average $\mathrm{NO}_{3}-\mathrm{N}$ (std. dev.) ${ }^{\mathrm{a}}$ & Median $\mathrm{NO}_{3}-\mathrm{N}$ & $\%$ nondetects \\
\hline \multicolumn{5}{|l|}{ Wells mg/l } \\
\hline \multirow{2}{*}{ 2001-2003 - cropped ${ }^{b}$} & Upland & $10.6(3.0)$ & 11.0 & 0 \\
\hline & Drainageway & $2.5(3.9)$ & 0.2 & 55 \\
\hline \multirow[t]{3}{*}{ 2004-2006 - transition } & Upland & $10.7(3.9)$ & 12.0 & 0 \\
\hline & Footslope & $10.2(6.3)$ & 9.3 & 7 \\
\hline & Drainageway & $3.7(5.1)$ & 0.5 & 42 \\
\hline \multirow[t]{3}{*}{ 2007-2009 - prairie } & Upland & $2.1(1.7)$ & 1.5 & 4 \\
\hline & Footslope & $1.3(2.5)$ & 0.2 & 60 \\
\hline & Drainageway & $0.2(0.1)$ & 0.2 & 95 \\
\hline \multicolumn{5}{|l|}{ Suction cup - $1.2 \mathrm{~m}$} \\
\hline \multirow[t]{3}{*}{ 2004-2006 - transition } & Upland & $5.0(7.3)$ & 1.11 & 35 \\
\hline & Footslope & $5.4(7.3)$ & 1.71 & 33 \\
\hline & Drainageway & $2.4(3.6)$ & 0.4 & 48 \\
\hline \multirow[t]{3}{*}{ 2007-2009 - prairie } & Upland & $0.2(0.2)$ & 0.2 & 92 \\
\hline & Footslope & $0.2(0.3)$ & 0.2 & 95 \\
\hline & Drainageway & $0.3(0.4)$ & 0.2 & 89 \\
\hline \multicolumn{5}{|l|}{ Suction cup - $2.4 \mathrm{~m}$} \\
\hline \multirow[t]{2}{*}{ 2004-2006 - transition } & Upland & $3.5(5.5)$ & 0.3 & 46 \\
\hline & Footslope & $8.9(7.0)$ & 8.2 & 9 \\
\hline \multirow[t]{2}{*}{ 2007-2009 - prairie } & Upland & $0.7(1.1)$ & 0.2 & 57 \\
\hline & Footslope & $0.2(0.2)$ & 0.2 & 87 \\
\hline
\end{tabular}

a Non-detectable concentrations were included in calculations at half the detection limit.

b Footslope monitoring installations were constructed in 2004; results not available 2001-2003.

organic-rich drainageways (Schilling et al., 2007). Variation in $\mathrm{NO}_{3}-$ $\mathrm{N}$ during the cropping period was greater within the drainageways than in the upland wells, despite a high frequency of non-detectable concentrations in the drainageways (Table 1 ). This is attributed to seasonalities associated with $\mathrm{N}$ fertilizer application, nitrification and leaching of applied and mineralized organic $\mathrm{N}$, and denitrification in the shallow and saturated receiving environment along the drainageways. Nitrate concentrations were observed to increase as soils warmed in spring, then decrease at a rate that could be attributed to denitrification (Schilling et al., 2007).

Following seeding of prairie vegetation, $\mathrm{NO}_{3}-\mathrm{N}$ concentrations showed changes that depended on landscape position, time, and depth/method of sampling (Table 1, Fig. 3). Trends of decreasing groundwater $\mathrm{NO}_{3}-\mathrm{N}$ concentrations during prairie reconstruction were statistically significant at every landscape position (Table 2), but were most evident once the transition to established prairie vegetation was becoming complete (Table 1). The decline in groundwater $\mathrm{NO}_{3}-\mathrm{N}$ resulting from the land use conversion to prairie reconstruction first became obvious in 2006, when concentrations along the drainageways decreased to less than $1 \mathrm{mg}$ $\mathrm{NO}_{3}-\mathrm{NL}^{-1}$ and remained at small concentrations (Fig. 3). Concurrently, $\mathrm{NO}_{3}-\mathrm{N}$ concentrations in the uplands first dropped below $10 \mathrm{mg} \mathrm{NO} \mathrm{NO}_{3}-\mathrm{N} \mathrm{L}^{-1}$ during 2006 and became relatively stable around $2 \mathrm{mg} \mathrm{NO}_{3}-\mathrm{N} \mathrm{L}^{-1}$ during 2008 and 2009. Variation in $\mathrm{NO}_{3}-\mathrm{N}$ concentrations (Table 1, Fig. 3 ) also decreased during prairie reconstruction, especially along the ephemeral drainageways.

Nitrate concentration data from the suction cup samplers also showed decreasing $\mathrm{NO}_{3}-\mathrm{N}$ concentration with time (Tables 1 and 3). Decreasing trends in $\mathrm{NO}_{3}-\mathrm{N}$ were significant in virtually every case, regardless of landscape position, sampling method (well or suction sampler), depth, or which non-parametric correlation method was used (Tables 2 and 3 ). There was a single exception (Table 3 ), which had a $p$ value of 0.06 . Nitrate concentrations in waters collected from suction cup samplers could not be statistically distinguished among landscape positions, however, due to the prevalence of non-detectable concentrations after 2005 , which became the median and modal concentration during 2006 and in subsequent years (Fig. 3, lower plot).

The decrease in groundwater $\mathrm{NO}_{3}-\mathrm{N}$ concentrations lags the prairie reconstruction planting, and the lag's duration increased upslope along a topographic sequence of individual wells (Fig. 4). The topographically lowest well (MW3), near the outlet of the watershed, showed $\mathrm{NO}_{3}-\mathrm{N}$ concentrations less than $1 \mathrm{mg} / \mathrm{l}$ throughout the monitoring period. Two wells located along the upper drainageway (MW11) and the footslope position (TT3) drop to non-detectable concentrations during 2006, within 3 years after prairie seeding. Two upland wells (MW8, MW16) then respond during 2007, or within 4 years after the prairie seeding, but the steeper decline was in MW16 (see Fig. 4), which was closest to the drainageway and at a surface elevation about $1.8 \mathrm{~m}$ lower than MW8. These uppermost wells may continue to decline towards non-detectable concentrations; depending on results of further monitoring and impacts of climatic cycles and disturbance (particularly fire) effects in the longer term.

Wet conditions occurred during 2008 when there was significant flooding in much of Iowa, and there was a significant increase in groundwater levels at this site that year. Upland water tables on average came within nearly $1.1 \mathrm{~m}$ of the surface during summer 2008, then declined to nearly $4 \mathrm{~m}$ depth during summer 2009 (data not shown). The responsiveness of the water table is not only caused by weather patterns and plant water use, but also by the low specific yield of the fine textured and relatively dense tills compris-

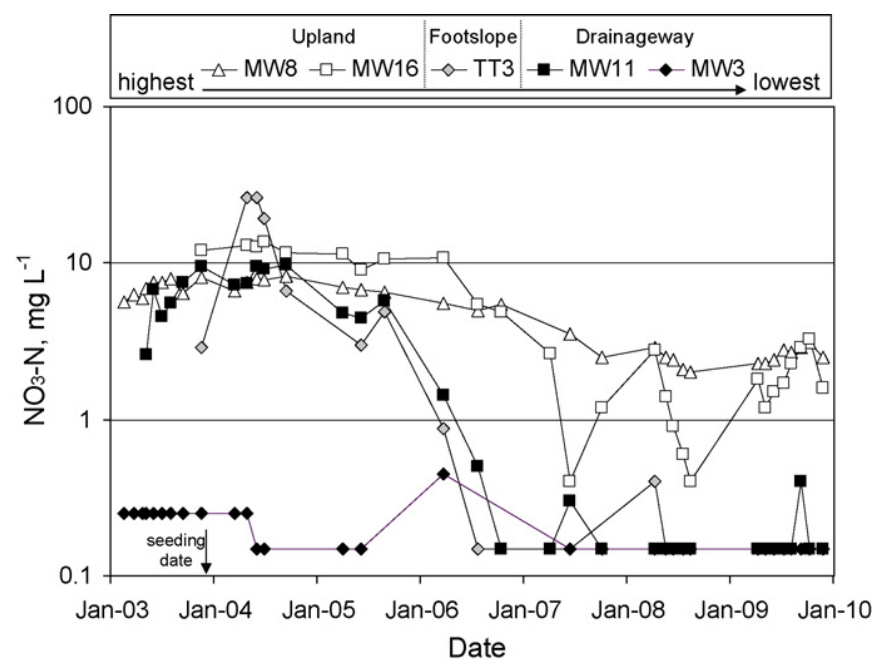

Fig. 4. Groundwater $\mathrm{NO}_{3}-\mathrm{N}$ concentrations during prairie reconstruction along a topographic sequence of wells that is located in Fig. 2. 
Table 2

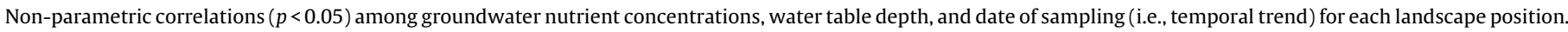
Spearman rank correlation coefficients are above the diagonals (of ' 1 ' values), Kendall Tau-b coefficients are below.

\begin{tabular}{|c|c|c|c|c|}
\hline Landscape position & Date & $\mathrm{NO}_{3}-\mathrm{N}$ & Phosphorus & Water table depth \\
\hline \multicolumn{5}{|l|}{ Upland } \\
\hline Date & 1 & -0.73 & $\times$ & -0.17 \\
\hline $\mathrm{NO}_{3}-\mathrm{N}$ & -0.49 & 1 & -0.48 & 0.20 \\
\hline Phosphorus & $\times$ & -0.34 & 1 & -0.34 \\
\hline Water table depth & -0.10 & 0.14 & -0.25 & 1 \\
\hline \multicolumn{5}{|l|}{ Footslope } \\
\hline Date & 1 & -0.73 & $\times$ & 0.28 \\
\hline $\mathrm{NO}_{3}-\mathrm{N}$ & -0.53 & 1 & -0.52 & 0.35 \\
\hline Phosphorus & $\times$ & -0.37 & 1 & -0.57 \\
\hline Water table depth & $\times$ & 0.26 & -0.41 & 1 \\
\hline \multicolumn{5}{|l|}{ Drainageway } \\
\hline Date & 1 & -0.65 & $\times$ & $\times$ \\
\hline $\mathrm{NO}_{3}-\mathrm{N}$ & -0.44 & 1 & $\times$ & $x$ \\
\hline Phosphorus & $\times$ & $x$ & 1 & $\times$ \\
\hline Water table depth & $\times$ & $x$ & $x$ & 1 \\
\hline
\end{tabular}

Note: $\times$ indicates $p>0.05$.

ing upland subsoils at this site. Significant water table fluctuations can occur in response to relatively small amount of recharge. At a nearby site, Asbjornsen et al. (2007) estimated the specific yield of these tills could be as small as 0.02 (units of depth-equivalent recharge required to produce one unit rise in ground water level).

The water table's fluctuation has implications for the observed lag in decreased upland $\mathrm{NO}_{3}-\mathrm{N}$ concentrations. This lag may not be attributable to a deeper water table and greater time-of-travel required for leached $\mathrm{NO}_{3}-\mathrm{N}$ to reach the water table in upland positions, as reported for a western Iowa site (Tomer and Burkart, 2003). Rather, soil core data indicate that at the beginning of the prairie reconstruction, there was a greater supply of mineral and/or mineralizable $\mathrm{N}$ in the upland soils that was susceptible to leaching, compared to soils along the ephemeral drainageways. This statement is based on C: $\mathrm{N}$ ratios of subsoils at the site (Fig. 5). Literature suggests that enhanced $\mathrm{N}$ leaching should be anticipated if the C:N mass concentration ratio is 10:1 or less (Schipper et al., 2004). Soil data from this site indicate the organic $\mathrm{C}$ : total $\mathrm{N}$ ratio was less than 10 near the beginning of reconstruction, and indeed as low as 5.7, at depths below $0.5 \mathrm{~m}$ in upland soils, whereas this ratio was not less than 10.6 in the drainageway soils. Soil $\mathrm{N}$ and $\mathrm{C}$ concentrations in the drainageways were similar to Walnut Creek riparian zone sediments (Schilling et al., 2009). In riparian soils at less than $1 \mathrm{~m}$ depth, percent $\mathrm{N}$ and $\mathrm{C}$ averaged $0.16 \pm 0.04$ and $1.79 \pm 0.57$, respectively, and $\mathrm{C}: \mathrm{N}$ ratios were hence greater than 10.5 . The smaller amount of organic carbon in upland soils at this site probably increased the susceptibility of soil $\mathrm{N}$ to leaching, contributing to a delay in the full attenuation of $\mathrm{NO}_{3}-\mathrm{N}$ leaching relative to drainageway soils. In another central Iowa watershed, Karlen et al. (2008) showed that upland soils also had smaller C: $\mathrm{N}$ ratios compared to poorly drained soils.

Monitoring results clearly indicate leaching of $\mathrm{NO}_{3}-\mathrm{N}$ from upland soils is decreasing with time since the planting of prairie vegetation. Despite heavy rainfall in 2008 and encroachment of the water table into the upland soil profile, little to no additional $\mathrm{N}$ leaching was apparent in 2008 (Fig. 3). An increase in subsurface $\mathrm{NO}_{3}-\mathrm{N}$ is typically observed following periods of seasonal recharge in agricultural watersheds (Tomer et al., 2003), and following periods conducive to soil $\mathrm{N}$ mineralization (Cambardella et al., 1999). However, beneath the reconstructed prairie, seasonal fluctuation in $\mathrm{NO}_{3}-\mathrm{N}$ became diminished. Seasonal oscillation in groundwater and soil water $\mathrm{NO}_{3}-\mathrm{N}$ were evident in 2008 and 2009 (Figs. 3 and 4), but the magnitude of fluctuations in $\mathrm{NO}_{3}-\mathrm{N}$ concentration was small $(<1 \mathrm{mg} / \mathrm{l})$. Data from suction cup samplers showed a strong decrease in $\mathrm{NO}_{3}-\mathrm{N}$ concentration in upland soil water occurred during the first 2 years after prairie plant-

\section{Table 3}

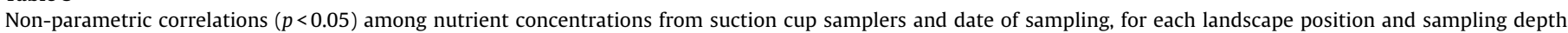
Spearman rank correlation coefficients are above the diagonals (of ' 1 ' values), and Kendall Tau-b coefficients are given below.

\begin{tabular}{|c|c|c|c|}
\hline Landscape position and depth & Date & $\mathrm{NO}_{3}-\mathrm{N}$ & Phosphorus \\
\hline \multicolumn{4}{|l|}{ Upland - $1.2 \mathrm{~m}$} \\
\hline Date & 1 & -0.59 & -0.39 \\
\hline $\mathrm{NO}_{3}-\mathrm{N}$ & -0.46 & 1 & $x$ \\
\hline Phosphorus & -0.32 & $x$ & 1 \\
\hline \multicolumn{4}{|l|}{ Footslope $-1.2 \mathrm{~m}$} \\
\hline Date & 1 & -0.45 & $x$ \\
\hline $\mathrm{NO}_{3}-\mathrm{N}$ & -0.37 & 1 & $x$ \\
\hline Phosphorus & $x$ & $x$ & 1 \\
\hline \multicolumn{4}{|l|}{ Drainageway - $1.2 \mathrm{~m}$} \\
\hline Date & 1 & -0.27 & $x$ \\
\hline $\mathrm{NO}_{3}-\mathrm{N}$ & -0.22 & 1 & $x$ \\
\hline Phosphorus & $x$ & $x$ & 1 \\
\hline \multicolumn{4}{|l|}{ Upland - $2.4 \mathrm{~m}$} \\
\hline Date & 1 & -0.19 & $x$ \\
\hline $\mathrm{NO}_{3}-\mathrm{N}$ & $x$ & 1 & -0.30 \\
\hline Phosphorus & $x$ & -0.26 & 1 \\
\hline \multicolumn{4}{|l|}{ Footslope $-2.4 \mathrm{~m}$} \\
\hline Date & 1 & -0.82 & $x$ \\
\hline $\mathrm{NO}_{3}-\mathrm{N}$ & -0.69 & 1 & 0.39 \\
\hline Phosphorus & $x$ & 0.33 & 1 \\
\hline
\end{tabular}

Note: $\times$ indicates $p>0.05$. 


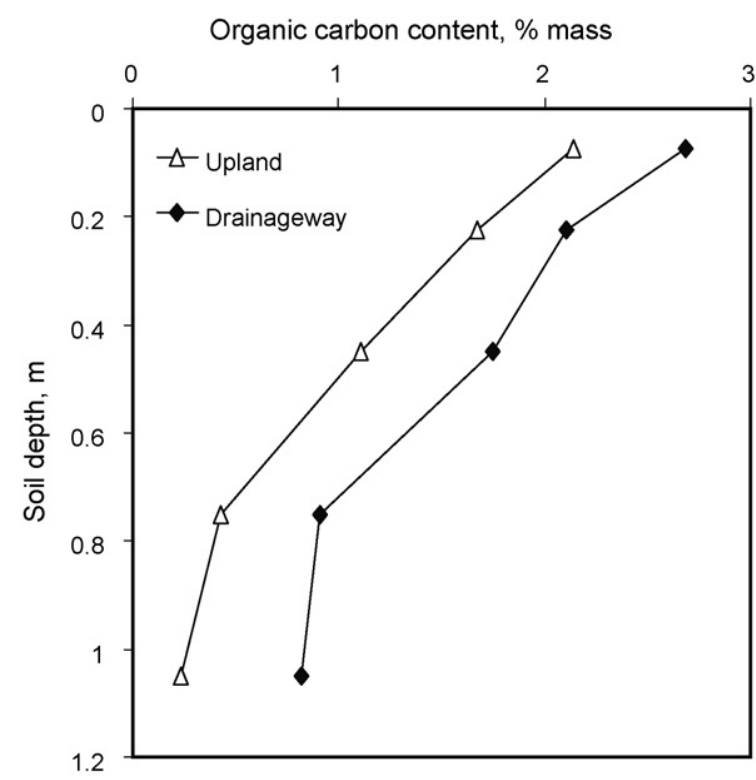

Carbon : Nitrogen ratio, mass/mass

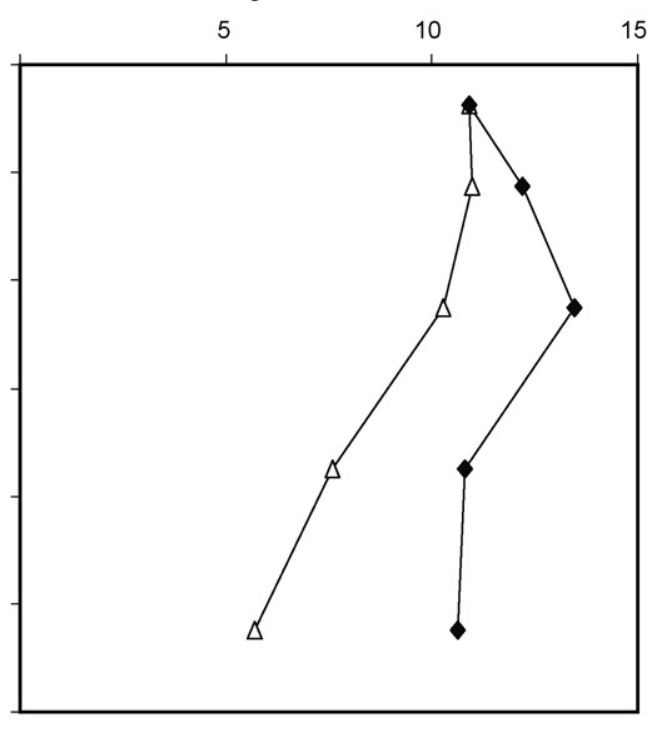

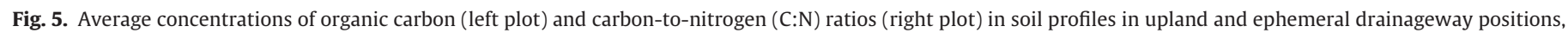
measured in cores collected during autumn 2003.

ing (Fig. 3, lower part). After 2006, little $\mathrm{NO}_{3}-\mathrm{N}$ was detected in soil water in upland areas. We hypothesize that most $\mathrm{N}$ remaining in upland soils following 6 years of prairie reconstruction is in slowly-mineralizable forms and/or being actively cycled within the prairie plant community. Continued monitoring will show if and when upland groundwater $\mathrm{NO}_{3}-\mathrm{N}$ will begin to frequent the non-detectable levels observed along the drainageways within 3-4 years of prairie planting. This will depend on vegetation dynamics and nutrient cycling in the developing prairie ecosystem and the influences of climate and management, particularly fire which can increase mineral pools of soil $\mathrm{N}$ that are susceptible to leaching (Wan et al., 2001).

Schilling et al. (2007) showed that groundwater in the drainageways had greater ammonium than upland groundwater. However, ammonium monitoring since 2006 showed $92 \%$ of groundwater samples collected after 2005 had non-detectable $\mathrm{NH}_{4}-\mathrm{N}$ concentrations. In saturated drainageway soils, ammonia production (through mineralization of organic $\mathrm{N}$ and/or dissimilatory $\mathrm{NO}_{3}$ reduction, see Burgin and Hamilton, 2007) became abated within a few years after prairie planting.

\subsection{Comparing $\mathrm{NO}_{3}-\mathrm{N}$ record to refuge-wide chronosquence results}

In a general sense, $\mathrm{NO}_{3}-\mathrm{N}$ monitoring in a single small catchment over time produced similar results compared to a 'snapshot' of monitoring data across a 13 year chronosequence of upland soils across NSNWR (Schilling and Jacobson, 2010). Both approaches showed a significant decrease in groundwater $\mathrm{NO}_{3}-\mathrm{N}$ concentrations occurring with time since prairie reconstruction (Fig. 6). However, estimated rates of $\mathrm{NO}_{3}-\mathrm{N}$ decrease following land cover change were different when comparing the single catchment to the basin-wide chronosequence study (Fig. 6). The linear model fit to the chronosequence data appeared to under-represent the rate of $\mathrm{NO}_{3}-\mathrm{N}$ decrease observed in the upland catchment. The exponential decay model from the chronosequence study provided a better fit to the upland catchment results, with both methods showing groundwater $\mathrm{NO}_{3}-\mathrm{N}$ concentrations 6 years after planting around $2 \mathrm{mg} / \mathrm{l}$. However, the lag time observed in the upland catchment was not captured in the basin-wide chronosequence study.
Lag times within the chronosequence study sites probably became "averaged" out in the basin-wide comparison, because the duration of the lag is site-specific, and the initial $\mathrm{NO}_{3}-\mathrm{N}$ concentration was only known for chronosequence sites that were not yet planted to prairie vegetation. The data presented here attest to the variability that exists within a single, one-owner field: both $\mathrm{NO}_{3}-\mathrm{N}$ concentration decreases and lag durations varied within this single site. The variability across all NSNWR prairie reconstructions could be considerably greater. Note that, even though a linear trend for this site's upland groundwater $\mathrm{NO}_{3}-\mathrm{N}$ data by definition does not specify a lag, that the $R^{2}$ for the linear model was nearly 0.70 , compared to 0.38 in the chronosequence study. This difference in $R^{2}$ probably reflects the difference in variation between the two scales. Nonetheless, the relative consistency between the two approaches provides assurance that the $\mathrm{NO}_{3}-\mathrm{N}$ concentration reductions are valid.

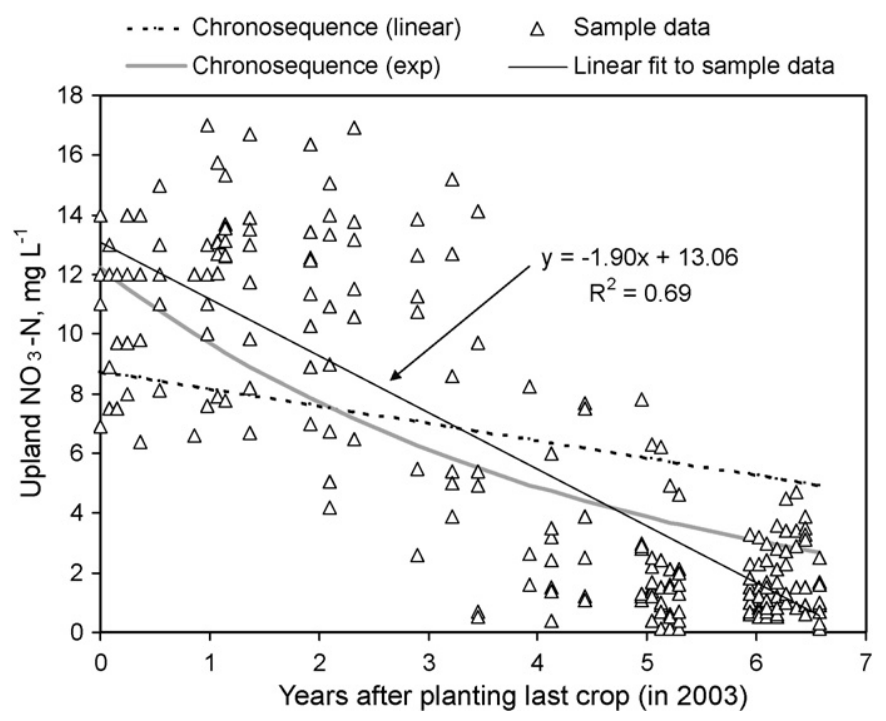

Fig. 6. Comparison of upland groundwater monitoring data and its temporal trend to linear and exponential trends found in a chronosequence of NSNWR prairie reconstructions (Schilling and Jacobson, 2010). Date zero was set to May 7, 2003 because cropped fields were assigned year zero in the chronosequence study. 
Table 4

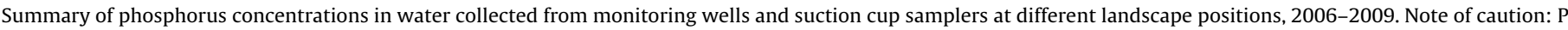

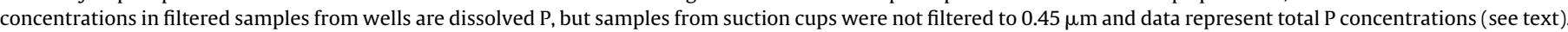

\begin{tabular}{|c|c|c|c|c|}
\hline Sampling method/depth & Landscape position & Average $\mathrm{P}(\text { std. dev. })^{\mathrm{a}}(\mathrm{mg} / \mathrm{l})$ & Median P (mg/l) & $\%$ nondetects \\
\hline \multicolumn{5}{|l|}{ Wells } \\
\hline & Upland & $0.024(0.016)$ & 0.020 & 15 \\
\hline & Footslope & $0.147(0.126)$ & 0.175 & 8 \\
\hline & Drainageway & $0.109(0.065)$ & 0.115 & 3 \\
\hline \multicolumn{5}{|c|}{ Suction cup samplers, $1.2 \mathrm{~m}$} \\
\hline & Upland & $0.020(0.045)$ & 0.010 & 70 \\
\hline & Footslope & $0.047(0.050)$ & 0.010 & 53 \\
\hline & Drainageway & $0.099(0.373)$ & 0.040 & 26 \\
\hline \multicolumn{5}{|l|}{ Suction cup samplers, $2.4 \mathrm{~m}$} \\
\hline & Upland & $0.024(0.013)$ & 0.020 & 26 \\
\hline & Footslope & $0.124(0.136)$ & 0.040 & 14 \\
\hline
\end{tabular}

a Calculations include non-detectable concentrations assigned at one half the detection limit.

\subsection{Phosphorus}

Patterns of phosphorus concentrations differed from those of $\mathrm{NO}_{3}-\mathrm{N}$, in that there was little evidence of a temporal trend (Fig. 7), and that differences among landscape positions contrasted those found for $\mathrm{NO}_{3}-\mathrm{N}$. Dissolved $\mathrm{P}$ concentrations in groundwater were greater in footslope and drainageway positions than in the uplands (Table 4, Fig. 7). There were also negative correlations between $\mathrm{NO}_{3}-\mathrm{N}$ and dissolved $\mathrm{P}$ concentrations in groundwater and in 2.4$\mathrm{m}$ depth suction cup samplers, at upland and footslope positions (Tables 2 and 3). This is not unexpected because anaerobic conditions that encourage removal of $\mathrm{NO}_{3}-\mathrm{N}$ via denitrification also encourage the release of $\mathrm{Fe}$ bound $\mathrm{P}$ into solution by reducing Fe from ferric to ferrous form. In addition, two mechanisms have
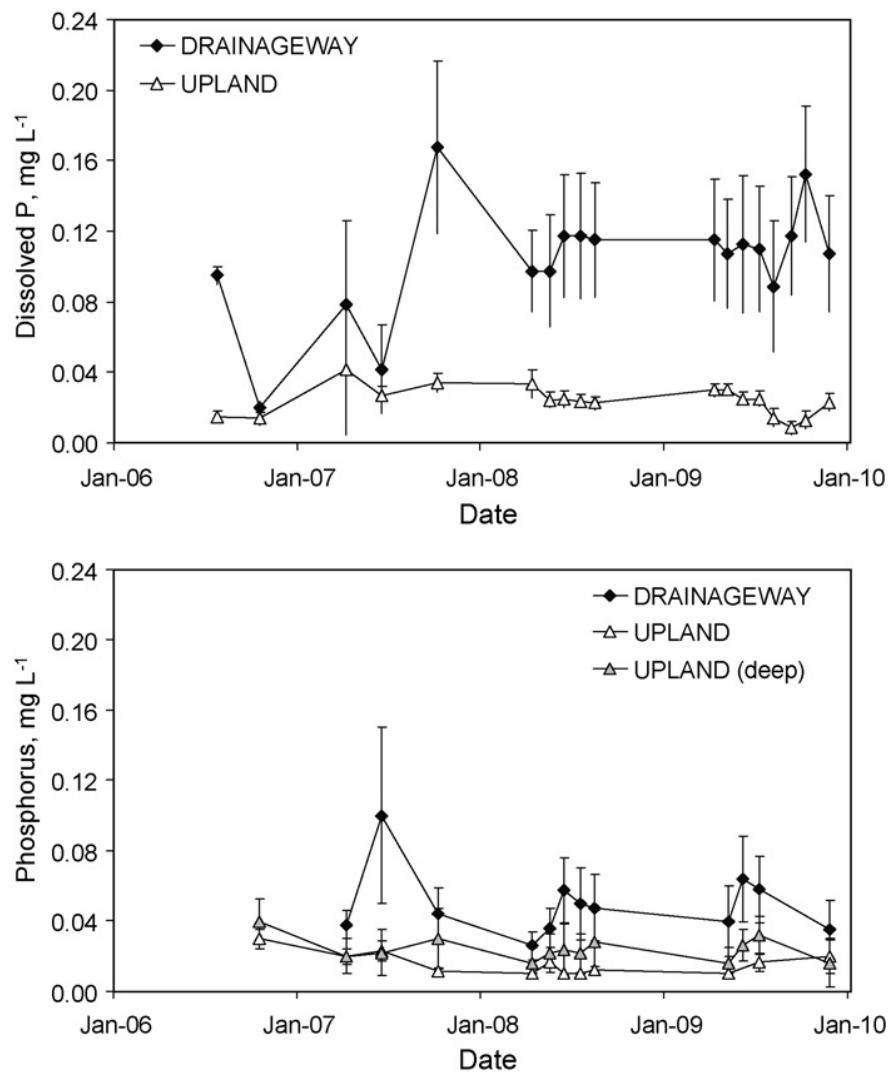

Fig. 7. Upper plot: average dissolved phosphorus concentrations in groundwater collected from wells in upland positions and along ephemeral drainageways. Lower plot: average phosphorus concentrations in soil water from suction cup samplers in uplands (1.2 and $2.4 \mathrm{~m}$ depth) and drainageways (1.2 $\mathrm{m}$ depth). Error bars indicate standard deviation. been proposed by which $\mathrm{NO}_{3}-\mathrm{N}$ may lead to increased P solubility in groundwater; one through release of Ca-bound $\mathrm{P}$ into solution by soil acidification that occurs through nitrification of $\mathrm{NH}_{3}-\mathrm{N}$ (Browne et al., 2008), the other through oxidation of $\mathrm{FeS}_{2}$ by $\mathrm{NO}_{3}$, producing sulfate that may interfere with Fe fixation of $\mathrm{P}$ and/or enhance release of organic P (Smolders et al., 2009).

But these biogeochemical processes may only partly explain why dissolved P concentrations in groundwater were greatest in drainageway and footslope positions. There is evidence that a history of sediment deposition along the drainageways, and at footslopes above the ephemeral drainageways (where two footslope wells showing high $\mathrm{P}$ were located) provides a supply of soil $\mathrm{P}$ that could leach into shallow groundwater at these positions. While the site was cropped, the northern drainageway was planted into grassed waterways to prevent the gully formation. Grassed areas below annual crops trap sediment eroded from surface soils that commonly have phosphorus fertilizers applied to them. Schilling et al. (2007) logged the presence of post-settlement alluvium (deposition of sediment eroded from upland soils while cropped) along both the drainageways. Footslope positions occur where decreased slope will decrease runoff velocity and can hence accumulate sediment eroded from adjacent uplands. The accumulation of $\mathrm{P}$ in this trapped sediment may then become susceptible to leaching, given these areas also receive run-on water generated upslope. Correlations show increased $\mathrm{P}$ concentrations when the water table was shallow in uplands, but especially at footslope positions (Table 2), which suggest release of $P$ from surface soils to groundwater. Tomer et al. (2007) showed how the edge of a riparian buffer, particularly those areas most prone to receive runoff from upslope, exhibited measurable sediment accretion, and had greater $P$ concentrations in water sampled from suction cup samplers and shallow wells compared to cropped areas. In addition, a well transect across the Walnut Creek floodplain showed significantly greater $P$ concentrations in groundwater beneath post-settlement alluvium $(0.26 \mathrm{mg} / \mathrm{l})$ than beneath upland loess and till $(0.04 \mathrm{mg} / \mathrm{l})$ (Schilling and Jacobson, 2008). Shallow groundwater with conditions conducive to denitrification can clearly exhibit high $\mathrm{P}$ concentrations, especially where there is a history of accumulation of P-rich sediments.

Evidence for temporal trends in $\mathrm{P}$ concentration were weak (Tables 2 and 3); although a decreasing trend was noted for shallow $(1.2 \mathrm{~m})$ suction cup samplers in the uplands. The chronosequnce study by Schilling and Jacobson (2010) also found no evidence for a trend in groundwater P concentrations. Because P may not be removed from reduced groundwater except by biological uptake and physical transport, a short period of monitoring (2006-2009) is not sufficient to observe a trend. Biological uptake of $P$ from groundwater would be slow process and groundwater transport from the watershed has been estimated to take decades, based on groundwater modeling (Schilling et al., 2007). The large P concen- 
trations near the surface present a risk for overland transport. At times of ample precipitation, if the water table along the drainageways reaches the surface, then saturation-excess overland flow may occur, delivering groundwater $P$ to surface waters by overland flow. Note that average $P$ concentrations along the drainageways are about $0.1 \mathrm{mg} / \mathrm{l}$, which are sufficiently large to pose a risk of eutrophication to nearby surface waters (Dodds and Welch, 2000). Burkart et al. (2004) also reported a range of groundwater phosphorus concentrations exceeding $0.1 \mathrm{mg} \mathrm{PL}^{-1}$, which included data from four agricultural sites in Iowa (not including NSNWR). They did not evaluate variation due to landscape position, but concluded by expressing concern for eutrophication risk from groundwater $\mathrm{P}$ in Iowa.

\section{Conclusions}

Groundwater monitoring during 6 years of prairie reconstruction at an agricultural site showed $\mathrm{NO}_{3}-\mathrm{N}$ concentrations declined and stabilized within 5 years after planting perennial vegetation. However, there was a lagged response, and declines in groundwater $\mathrm{NO}_{3}-\mathrm{N}$ were not obvious until nearly 3 years after planting, when the prairie became fully established. This lag time was consistent with results of small watershed research elsewhere. The lag in $\mathrm{NO}_{3}-\mathrm{N}$ decline and the rate at which the $\mathrm{NO}_{3}-\mathrm{N}$ concentration declined varied with landscape position. Non-detectable $\mathrm{NO}_{3}-\mathrm{N}$ concentrations dominated along drainageways within 3 years, but in uplands it took 5 years for $\mathrm{NO}_{3}-\mathrm{N}$ concentrations to stabilize near $2 \mathrm{mg} \mathrm{NO}_{3}-\mathrm{N} \mathrm{L}^{-1}$. This difference was attributed to low carbon stocks and $\mathrm{C}: \mathrm{N}$ ratios in upland subsoils, suggesting greater pools of mineral and mineralizable $\mathrm{N}$ in upland soils. The rate of decrease in upland groundwater nitrate averaged $1.9 \mathrm{mg} \mathrm{NO}_{3}-\mathrm{N} \mathrm{L}^{-1}$ year ${ }^{-1}$, a rate greater than but not inconsistent with results from a multi-site chronosequence study at NSNWR.

Phosphorus showed a contrasting pattern to $\mathrm{NO}_{3}-\mathrm{N}$, with no clear temporal trend. The greatest $\mathrm{P}$ concentrations in groundwater occurred along the ephemeral drainageways. The shallow groundwater along the drainageways could rise to become saturation-excess runoff, and observed P concentrations would then present a risk of eutrophication to surface waters. Along the drainageways and at footslopes, sediment has accumulated due upland erosion when soils were cropped. These accumulated sediments are a likely source of $P$ to shallow groundwater in the drainageways, where reduced geochemical conditions may lead to $P$ release. Therefore, groundwater $P$ may represent a long-term impact of agriculture at this prairie ecosystem reconstruction site. This result suggests a legacy impact of agricultural soil erosion on water quality that may occur even if the eroded soil is not transported off site.

\section{Acknowledgments}

Thanks to Colin Greenan and Jeff Cook for assistance with installations, sampling, and data collation. The topographic survey of the site was conducted by Kevin Cole and Jeff Nichols.

\section{References}

APHA, 1998. Standard Methods for the Examination of Water and Wastewater (Method 10-107-06-2-A), twentieth ed. American Public Health Association, American Water Works Association, and Water Environment Federation, Washington, DC.

Asbjornsen, H., Tomer, M.D., Gomez-Cardenas, M., Brudvig, L.A., Greenan, C.M., Schilling, K., 2007. Tree and stand transpiration in a Midwestern bur oak savanna after elm encroachment and restoration thinning. Forest Ecology and Management 247, 209-219.
Browne, B.A., Kraft, G.J., Bowling, J.M., DeVita, W.M., Mechenich, D.J., 2008. Collateral geochemical impacts of agricultural nitrogen enrichment from 1963 to 1985: a southern Wisconsin ground water depth profile. Journal of Environmental Quality 37 (4), 1456-1467.

Burgin, A.J., Hamilton, S.K., 2007. Have we overemphasized the role of denitrification in aquatic ecosystems? a review of nitrate removal pathways. Frontiers Ecology Environment 5 (2), 89-96.

Burkart, M.R., Simpkins, W.W., Morrow, A.J., and, J.M., Gannon, 2004. Occurrence of total dissolved phosphorus in unconsolidated aquifers and aquitards in Iowa. Journal of American Water Resources Association 40, 827-834.

Cambardella, C.A., Moorman, T.B., Jaynes, D.B., Hatfield, J.L., Parkin, T.B., Simpkins, W.W., Karlen, D.L., 1999. Water quality in Walnut Creek watershed: nitratenitrogen in soils, subsurface drainage water, and shallow groundwater. Journal of Environmental Quality 28, 25-34.

Dodds, W.K., Welch, E.B., 2000. Establishing nutrient criteria in streams. Journal of North American Benthological Society 19 (1), 186-196.

Grossman, J., Udluft, P., 2006. The extraction of soil water by the suction cup method: a review. European Journal of Soil Science 42, 83-93.

Jaynes, D.B., Dinnes, D.L., Meek, D.W., Karlen, D.L., Cambardella, C.A., Colvin, T.S., 2004. Using the late spring nitrate test to reduce nitrate loss within a watershed. Journal of Environmental Quality 33, 669-677.

Karlen, D.L., Tomer, M.D., Neppel, J., Cambardella, C.A., 2008. A preliminary watershed scale soil quality assessment in north central Iowa, USA. Soil Tillage Research 99, 291-299.

Meals, D.W., Dressing, S.A., Davenport, T.E., 2010. Lag time in water quality response to best management practices: a review. Journal of Environmental Quality 39, 85-96.

Nelson, D.W., Sommers, L.E., 1986. Total carbon, organic carbon, and organic matter. In: Klute, A. (Ed.), Methods of Soil Analysis Part 2: Chemical Microbiological Properties, second ed. ASA-SSSA, Madison, WI, pp. 539-579.

Nestrud, L.M., Worster, J.R., 1979. Soil survey of Jasper County, Iowa. In: USDA Soil Conservation Service and Iowa State University Cooperative Extension Service. US Government Printing Office, Washington, DC.

O'Dell, J.W. (Ed.), 1993. Method 365.1. Determination of Phosphorus by SemiAutomated Colorimetry. Environmental Monitoring Systems Laboratory, Office of Research and Development, USEPA, Cincinnati, OH.

Owens, L.B., Shipitalo, M.J., Bonta, J.V., 2008. Water quality response times to pasture management changes in small and large watersheds. Journal of Soil Water Conservation 63 (5), 292-299.

Prior, J.C., 1991. Landforms of Iowa. University of Iowa Press, Iowa City, IA.

SAS Institute, 2010. SAS 9.2 Documentation. SAS Institute, Cary, NC, http://support.sas.com/documentation/cdl_main verified March 302010.

Scherrod, L.A., Dunn, G., Peterson, G.A., Kolberg, R.L., 2002. Inorganic carbon analysis by modified pressure calcimeter method. Soil Science Society of America Journal 66, 299-305.

Schilling, K.E., Jacobson, P., 2008. Groundwater nutrient concentrations near an incised Midwestern stream: effects of floodplain lithology and land management. Biogeochemistry 87, 199-216.

Schilling, K.E., Jacobson, P., 2010. Groundwater conditions under a reconstructed prairie chronosequence. Agriculture, Ecosystems, and Environment 135, 81-89.

Schilling, K.E., Palmer, J.A., Bettis III, E.A., Jacobson, P., Schultz, R.C., Isenhart, T.M., 2009. Vertical distribution of total carbon, nitrogen and phosphorus in riparian soils of Walnut Creek, southern Iowa. Catena 77, 266-273.

Schilling, K.E., Spooner, J., 2006. Effects of watershed-scale land use change on stream nitrate concentrations. Journal of Environmental Quality 35, 2132-2145.

Schilling, K.E., Tomer, M.D., Zhang, Y.-K., Weisbrod, T., Jacobson, P., Cambardella, C.A. 2007. Hydrogeologic controls on nitrate transport in a small agricultural catchment, Iowa. Journal of Geophysical Research 112, doi:10.1029/2007JG000405, G03007.

Schipper, L.A., Percival, H.J., Sparling, G.P., 2004. An approach for estimating when soils will reach maximum nitrogen storage. Soil Use Management 20 (3), 281-286.

Smolders, A.J.P., Lucassen, E.C.H.E.T., Bobbink, R., Roelofs, J.G.M., Lamers, L.P.M., 2009 How nitrate leaching from agricultural lands provokes phosphate eutrophication in groundwater fed wetlands: the sulphur bridge. Biogeochemistry 98 , $1-7$.

Soil Survey Staff, 2003. Keys to Soil Taxonomy, ninth ed. USDA Natural Resource Conservation Service, Washington, DC

Tomer, M.D., Burkart, M.R., 2003. Long-term effects of nitrogen fertilizer use on ground water nitrate in two small watersheds. Journal of Environmental Quality $32,2158-2171$

Tomer, M.D., Meek, D.W., Jaynes, D.B., Hatfield, J.L., 2003. Evaluation of nitrate nitrogen fluxes from a tile drained watershed in central Iowa. Journal of Environmental Quality 32, 642-653.

Tomer, M.D., Moorman, T.B., Kovar, J.L., James, D.E., Burkart, M.R., 2007. Spatial patterns of sediment and phosphorus in a riparian buffer, western Iowa. Journal of Soil Water Conservation 62 (5), 329-338.

Wan, S., Hui, d., Luo, Y., 2001. Fire effects on nitrogen pools and dynamics in terrestrial ecosystems: a meta-analysis. Ecological Applications 11 (5), 1349-1365.

Wood, E.D., Armstrong, F.A.J., Richards, F.A., 1967. Determination of nitrate in sea water by cadmium-copper reduction to nitrite. Journal of Marine Biology 47, 23-31. 